\title{
The Comet assay for the detection of DNA damage in Mus spretus from Dot ana National Park
}

\author{
F. Festa, ${ }^{\text {a }}$ M. Cristaldi, ${ }^{b}$ L.A. Ieradi, ${ }^{c}$ S. Moreno, ${ }^{d}$ and R. Cozzi ${ }^{\mathrm{a}, *}$ \\ a Dipartimento di Biologia, Universitä degli Studi “'Roma TRE”, Viale G. Marconi 44600146 Rome, Italy \\ b Dipartimento di Biologia Animale e dell’Uomo, Universita “'La Sapienza”, Rome, Italy \\ ' Centro Studi Acidi Nucleici (CNR) c/o Dipartimento di Genetica Biologia, Molecolare, Universita “'La Sapienza’, Rome, Italy \\ ${ }^{\mathrm{d}}$ Estacion Biologica de Don̋ana, Consejo Superior de Investigaciones Cientificas, Seville, Spain
}

\begin{abstract}
Dot ana Park (Spain), a protected area in Europe, was affected by an environmental disaster in April 1998 that caused the spreading of acidic water and mud full of toxic metals from the Aznalcollar pyrite mine. In order to assess the contamination in the area and to monitor the possible biological effects of the toxic spill, a series of coordinated studies was performed utilizing several animal species living in that area. We performed genotoxicity monitoring using the Comet assay on peripheral blood leukocytes of the Algerian mouse (Mus spretus), a nonprotected rodent suitable as a bioindicator. The mice were sampled in different areas 6 months after the ecological disaster and again 1 year later. Our results showed that in 1998 all the areas examined were contaminated, as determined by an increase in the Comet assay parameters in the analyzed animals, whereas a significant decrease in the values of these parameters was observed in the 1999 samples, which were collected in a riverside area subject to tide flows. Thus, the Comet assay has proven to be an interesting and sensitive tool in studies of environmental genotoxicity.
\end{abstract}

Keywords: Genetic biomonitoring; DNA damages; Environmental pollution; Mus spretus; Doñ ana Park

\section{Introduction}

Don ana National Park, located in the Huelva province (SW Spain), is one of the largest protected areas in Europe. It has been declared a Reserve of the Biosphere by UNESCO and granted a European Diploma by the European Council. It has been protected from contamination, although in the last decade it has suffered from the increased impact of several human activities.

The Park receives water partly from the Guadiamar River, the last Guadalquivir tributary. In the north of Don ana Park, upstream of the Guadiamar River, lies the Aznalcollar pyrite mine, which generates acidic wastes stocked in a dam (Fig. 1).

On April 25, 1998, an important environmental disaster occurred when the Aznalcollar mine tailings pond broke, which dumped $4 \mathrm{hm}^{3}$ of acidic water and

\footnotetext{
*Corresponding author. Fax: +1-39-6-55176321.

E-mail address: cozzi@bio.uniroma3.it (R. Cozzi).
}

$2 \mathrm{hm}^{3}$ of mud full of toxic metals and arsenic into the Guadiamar River. Mud spread about $400 \mathrm{~m}$ on both sides of the banks and $40 \mathrm{~km}$ downstream, and water continued to flow $20 \mathrm{~km}$ further downstream, being retained by a wall which was built in urgency in "Entremuros", (Grimalt et al., 1999). Entremuros is the name of the watercourse of the lower segment of the river Brazo de la Torre confined by walls constructed along both riversides.

From May to October 1998, mud was removed and the Entremuros water was treated with a water depuration system to limit toxic spillage into the Park (Martin et al., 2000).

In order to assess the contamination levels and monitor the possible biological effects of the toxic spill, a series of coordinated studies was performed utilizing several animal species living in the area (Benito et al., 1999; Blasco et al., 1999) and using different types of analyses (Ruiz-Laguna et al., 2001). The monitoring of the genotoxic effects in the environment required the selection of representative organisms as sentinels, as well 



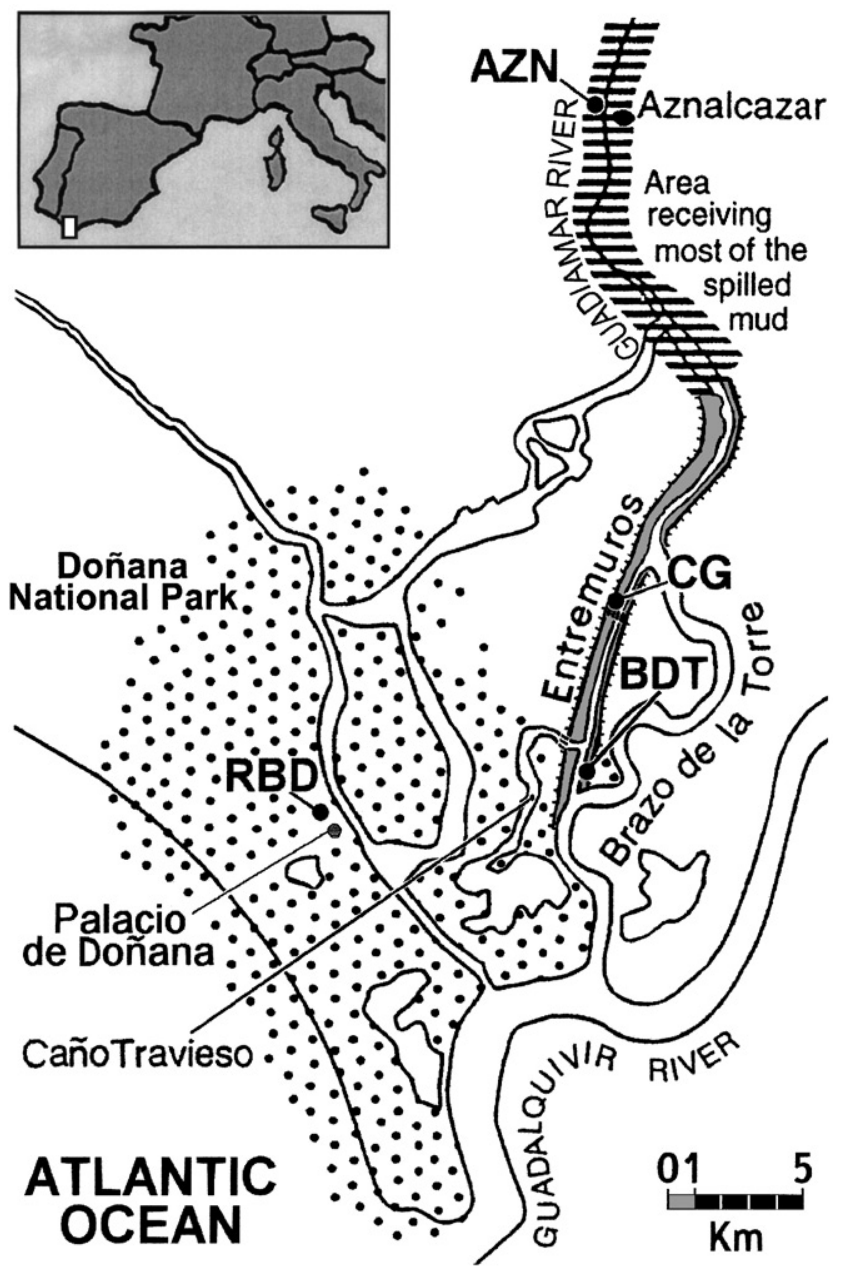

Fig. 1. Map of the Guadiamar River (modified by Grimalt et al., 1999) from the polluted tract (parallel lines) to its mouth in the Guadalquivir River through Do* ana Park (dotted area). Sampling sites are indicated by the abbreviations in capital letters.

as the development of suitable and sensitive assays. Among these organisms, small mammals were preferentially selected, as they accumulate pollutants present in the environment and because of their high sensitivity (Cristaldi et al., 1985, 1990, 1991; Talmage and Walton, 1991; Ieradi et al., 1996).

Mus spretus (Lataste, 1883), commonly known as the Algerian mouse, is a nonprotected rodent attaining high population densities that lives in marshlands as the predominant small mammal (Cagnin et al., 1998), feeds in small areas around the capture site, and responds to metals, radionuclides, and plaguicides. Therefore, it is highly suitable as an "in situ" pollution bioindicator (Ieradi et al., 1998; Degrassi et al., 1999). Molecular and genetic studies have been performed on $\mathrm{M}$. spretus to assess the effects of the Aznalcollar disaster on Don ana Park (Ruiz-Laguna et al., 2001; Tanzarella et al., 2001).

In the present study, the single cell gel electrophoresis, or Comet, assay was applied for the first time on the peripheral blood leukocytes of $\mathrm{M}$. spretus to determine whether primary DNA damage was induced by the toxic spill in Don ana National Park. The test was performed on mice sampled from different areas of the Park and along the Guadiamar River 6 months after the ecological disaster (October 1998) and again 1 year later (October 1999).

The Comet assay provides a rapid, visual method for assessing DNA damage quantitatively in single cells and is established as a valuable tool in fundamental DNA damage and repair studies and in population biomonitoring (Visvardis et al., 1997, 2000). The alkaline Comet assay, in particular, allows us to detect DNA strand breaks and alkali labile sites (converted to breaks under alkaline conditions) which generate DNA fragments. During the electrophoresis, the fragments migrate and cells appear as "comets", with a bright fluorescent head and a tail the length and fluorescent intensity of which are related to the number of induced DNA strand breaks (for a review see Tice et al., 2000).

\section{Materials and methods}

\subsection{Study areas}

The four selected locations were the Aznalcazar (AZN) and Cangrejo Grande (CG) areas outside the park and the Brazo de la Torre (BDT) area and the La Aulaga area of Reserva Biologica de Don ana (RBD, also known as Doth ana Biological Reserve) inside the Park (Pain et al., 1998; Alzaga et al., 1999; Meharg et al., 1999).

The AZN site is located near Aznalcazar village, $25 \mathrm{~km}$ downstream of the broken tailing dam, and was covered by toxic sludge. The second site, CG, is close to the reservoir of the contaminated water, formed when the retaining wall was built. BDT is inside the Park downstream of the retaining wall and the RBDsite is about $10 \mathrm{~km}$ west of BDT (Fig. 1).

\subsection{Sampling sites}

A total of 87 M. spretus, 38 collected in October 1998 and 49 in October 1999 were analyzed. Animals were captured in live traps and taken alive to the "Bolin" laboratory of the Consejo Superior de Investigaciones Cientificas located in Doth ana Biological Reserve.

The home range of $\mathrm{M}$. spretus was considered to be within 25-107 m, in accord with the usual home range of the Mus genus, as estimated by Palomo (1990). We assumed that the animals collected in each location were of different reproductive units due to the restricted home range of this species. Therefore, as the limits of each trapping area were within the area of the above-mentioned home range, we believe that the 
collected mice spent their lifetimes inside the trapping areas.

The samples from each location showed variability in sex and age. Age was determined on the basis of body weight and length, dental erosion, and sexual maturity. In the 1998 sampling, 4 males and 7 females (2 juveniles and 9 adults) were sampled in AZN, 9 males and 6 females ( 7 juveniles and 8 adults) in CG, 4 males and 3 females (5 juveniles and 2 adults) in BDT, and 4 males and 1 female (1 juvenile and 4 adults) in RBD. In 1999, 6 males and 5 females ( 1 juvenile and 10 adults) were trapped in AZN, 6 males and 5 females (2 juveniles and 9 adults) in CG, 13 males and 4 females (10 juveniles and 7 adults) in BDT, and 5 males and 5 females (6 juveniles and 4 adults) in RBD.

The animals were killed by cervical dislocation and prepared immediately for analysis. Blood was collected in heparin by cardiac puncture, placed in vials with DMSO (0.1\%), and immediately frozen at $-801 \mathrm{C}$. The coolers were transported to the Italian laboratory 20 days after collection. The samples, retrieved as needed and quickly thawed in a 371C water bath, were analyzed in groups, selected randomly, in two successive years (1998 and 1999).

We also used blood samples from Mus domesticus (6 animals: 3 males and 3 females) collected in a negligibly contaminated area in the center of Italy. These samples were frozen at $-801 \mathrm{C}$ and then utilized together with the blood samples from M. spretus. This was a technical control to establish the method and avoid errors due to manipulation, freezing, and transport to the laboratory. This sampling served as the control group from a nonexposed area, although carried out in a sibiling species.

\subsection{Comet assay}

The alkaline Comet assay was performed as described by Singh et al. (1988), with some modifications. Whole blood $(20 \mathrm{~mL})$ was embedded in $180 \mathrm{~mL}$ of $0.7 \%$ lowmelting-point agarose in PBS (Ca and $\mathrm{Mg}$ free) at 371C and immediately pipetted onto a frosted glass microscope slide precoated with a layer of $1 \%$ normalmelting-point agarose similarly prepared in PBS. Two slides were prepared for each mouse, so that animals from different areas were processed for the assay and run randomly in the electhrophoresis unit. The agarose was allowed to set at $41 \mathrm{C}$ for the necessary time and the slides were incubated in a lysis solution $(2.5 \mathrm{M} \mathrm{NaCl}$, $10 \mathrm{mM}$ Tris- $\mathrm{HCl}, 100 \mathrm{mM} \mathrm{Na} 2 \mathrm{EDTA}, \mathrm{NaOH}$ to $\mathrm{pH} 10$, $1 \%$ Triton, $10 \%$ DMSO). After lysis, slides were placed onto a horizontal electrophoresis unit containing fresh buffer $\left(1 \mathrm{mM} \mathrm{Na} \mathrm{Na}_{2}\right.$ EDT, $300 \mathrm{mM} \mathrm{NaOH}, \mathrm{pH}$ 13) for $20 \mathrm{~min}$ to allow DNA unwinding. Electrophoresis was performed for $15 \mathrm{~min}$ at $25 \mathrm{~V}(300 \mathrm{~mA})$ at $41 \mathrm{C}$. Subsequently, slides were washed gently in a neutralization buffer solution for $5 \mathrm{~min}(0.4 \mathrm{M}$ Tris-HCl, $\mathrm{pH}$ 7.5), fixed in $100 \%$ fresh methanol for $3 \mathrm{~min}$, and stained with ethidium bromide $(2 \mathrm{mg} / \mathrm{mL})$. Stained nucleoids were scored visually using a fluorescence microscope (Leica) equipped with a camera. Fifty comets on each slide, coded and blindly scored, were acquired using an automatic image analysis system purchased from Delta Sistemi (Rome, Italy) to obtain 100 images for each mouse examined.

To quantify the induced DNA damage, we considered two parameters: the tail moment (TM) and the percentage of DNA in the tail. TM is a measure of the migrated DNA in the tail multiplied by the tail length (Olive et al., 1990). In both the tables and the figures, TM values are expressed in arbitrary units 7SE or 7SD. DNA \% in the tail is expressed as the proportion of DNA in the tail vs the total DNA in the Comet.

\subsection{Statistical analysis}

Analysis of variance (ANOVA) was applied and a $t$ test for independent groups was used to calculate the level of significance for differences in the mean value of TM and \% of DNA in the tail of mice collected in single sites. Furthermore, the nonparametric Mann-Whitney $\mathrm{U}$ test was used to compare the TM value shown by each mouse in each site. The level of significance was established at PO0:05: All analyses were carried out using the STATISTICA package.

\section{Results}

Fig. 1 is a map of the Guadiamar River from the Aznalcollar mine to its mouth at the Guadalquivir River through Doñ ana Park. Sampling sites are indicated by arrows in the AZN, CG, BDT, and RBD locations.

The mean values (7SD) of TM and \% DNA in the tail of M. spretus collected in the four sites are presented in Table 1. The two parameters for measuring DNA damage were used in agreement with the guidelines proposed by the expert panel for the use of the Comet assay in genetic toxicology (Tice et al., 2000). In this table, the data are separated into two classes of sampling: October 1998 and October 1999.

In the 1998 sampling, we found no significant differences among the mice collected in the four sites. On the contrary, when we observed the October 1999 sampling, TM values and DNA percentages in the AZN, CG, and RBDsamples were significantly higher than those in the BDT mice (for TM values: $\mathrm{P}=0.002,0.04$, 0.003 , respectively, using the $t$ test). Analyzing the $\%$ of DNA, we obtained quite similar results $(\mathrm{P}=0.007,0.03$, 0.04 , respectively).

Comparing the data from AZN, CG, and RBDmice collected in 1998 with those collected in 1999, TM values 
Table 1

Mean values of TM and \% of DNA in mice collected in four different sites

\begin{tabular}{|c|c|c|c|c|c|c|}
\hline \multirow[t]{2}{*}{ Site } & \multicolumn{3}{|c|}{ October 1998} & \multicolumn{3}{|c|}{ October 1999} \\
\hline & $\mathrm{N}$ & Tail moment 7 & in the tail $7 \mathrm{SD}$ & $\mathrm{N}$ & Tail moment 7 & in the tail $7 \mathrm{SD}$ \\
\hline $\mathrm{AZN}$ & 11 & 24.22717 .74 & 25.2717 .6 & 11 & $22.24723 .32^{\mathrm{a}}$ & 24.5721 .4 \\
\hline CG & 15 & 30.37721 .83 & 29.7719 .6 & 11 & $16.93727 .15^{b}$ & 21.2725 .6 \\
\hline BDT & 7 & $38.28726 .30^{c}$ & 32.8719 & 17 & 2.4472 .95 & 676.7 \\
\hline RBD5 & & 13.8878 .95 & 13.476 .4 & 10 & $21.08723 .21^{\mathrm{d}}$ & 18.8721 .8 \\
\hline
\end{tabular}

${ }^{\mathrm{a}} \mathrm{AZN}$ 4BDT, $\mathrm{P}=0.002$, $\mathrm{t}$ test. ${ }^{\mathrm{b}}$

CG4BDT, $\mathrm{P}=0.04$, t test. ${ }^{\mathrm{c}}$

BDT1998 CBDT1999, P\{0:0001; t test. ${ }^{\mathrm{d}}$

RBD4BDT, $\mathrm{P}=0.003$, $\mathrm{t}$ test.

Table 2

Comparison of TM values between 1998 and 1999 samples by gender and age

\begin{tabular}{|c|c|c|c|c|}
\hline \multirow[t]{2}{*}{ Gender } & \multicolumn{2}{|c|}{ October 1998} & \multicolumn{2}{|c|}{ October 1999} \\
\hline & $\mathrm{N}$ & Tail moment 7SD & $\mathrm{N}$ & Tail moment 7 SD \\
\hline Females & 17 & 30.12726 .54 & 19 & 21.2724 .69 \\
\hline Males & 21 & 26.07715 .56 & 30 & 9.35717 .6 \\
\hline \multicolumn{5}{|l|}{ Age } \\
\hline Juveniles & 15 & 38.9724 .8 & 19 & 9.45716 .23 \\
\hline Adults & 23 & 20.6714 .51 & 30 & 16.79723 .52 \\
\hline
\end{tabular}

Note: Age: juveniles 19984 juveniles 1999, P\{0.001 by ANOVA.

and the \% DNA in the tail showed no significant differences. On the contrary, the values for both parameters were significantly lower (P50.0001) in 1999 BDT mice than in 1998 BDT mice.

In Table 2, data are presented for gender and age. The ANOVA show no significant differences between the TM values observed in all females and males collected in the two samplings (1998 and 1999). Also, when we compared the TM values of males and females collected in 1998 with those collected in 1999, we found no significant differences.

The comparison between all juveniles and all adult mice (1998 plus 1999) shows no significant differences in TM values. A significant (ANOVA: $F=6.348$; $\mathrm{P}=0.0006$ ) difference was observed when we compared juveniles sampled in 1998 with those sampled in 1999. A significantly (Po0.001) lower value was observed in 1999 juveniles in comparison with 1998 juveniles (Table 2).

Figs. 2 and 3 show the mean TM7SE (in the graphs) and the numerical values of TM7SD(in the adjacent tables) for each mouse collected in the four sites, both in 1998 and in 1999. TM values were analyzed with a Mann-Whitney nonparametric test. In the AZN and CG sites, the data were indicative of high interindividual variability (Fig. 2). Comparing the TM values for each mouse collected in CG in 1998 with those for each collected in 1999, we found a slight but significant (PO0.05) decrease. No differences were found between the 1998 and 1999 AZN samples. Fig. 3 illustrates the data from the BDT and RBD samples. In the BDT mice, the interindividual variability present in the 1998 sampling was not found in the 1999 mice, with a substantial reduction of the TM in all animals examined (PO0.005). In the RBDsite, despite the interindividual variability increase in the 1999 sampling, there was no statistically significant difference between the two collection years.

\section{Discussion}

Numerous assays have been developed to monitor biological hazards caused by contaminants. Genotoxicity studies have been conducted frequently on mammalian systems to evaluate the mutagenic potential associated with acute or chronic exposure to contaminants. Recently, particular attention has been devoted to the Comet assay in order to identify substances with genotoxic activity. This test allows DNA damage (single- and double-strand breaks, alkali labile lesions) to be detected in individual cells after acute and/or chronic exposure. Consequently, several genetic toxicology studies have been performed applying the Comet assay to every type of eukaryotic cell, including plant cells (Tice et al., 1991). In 1999, a paper appeared reviewing all data on the use of the Comet assay in genetic ecotoxicology (Cotelle and Ferard, 1999). The 

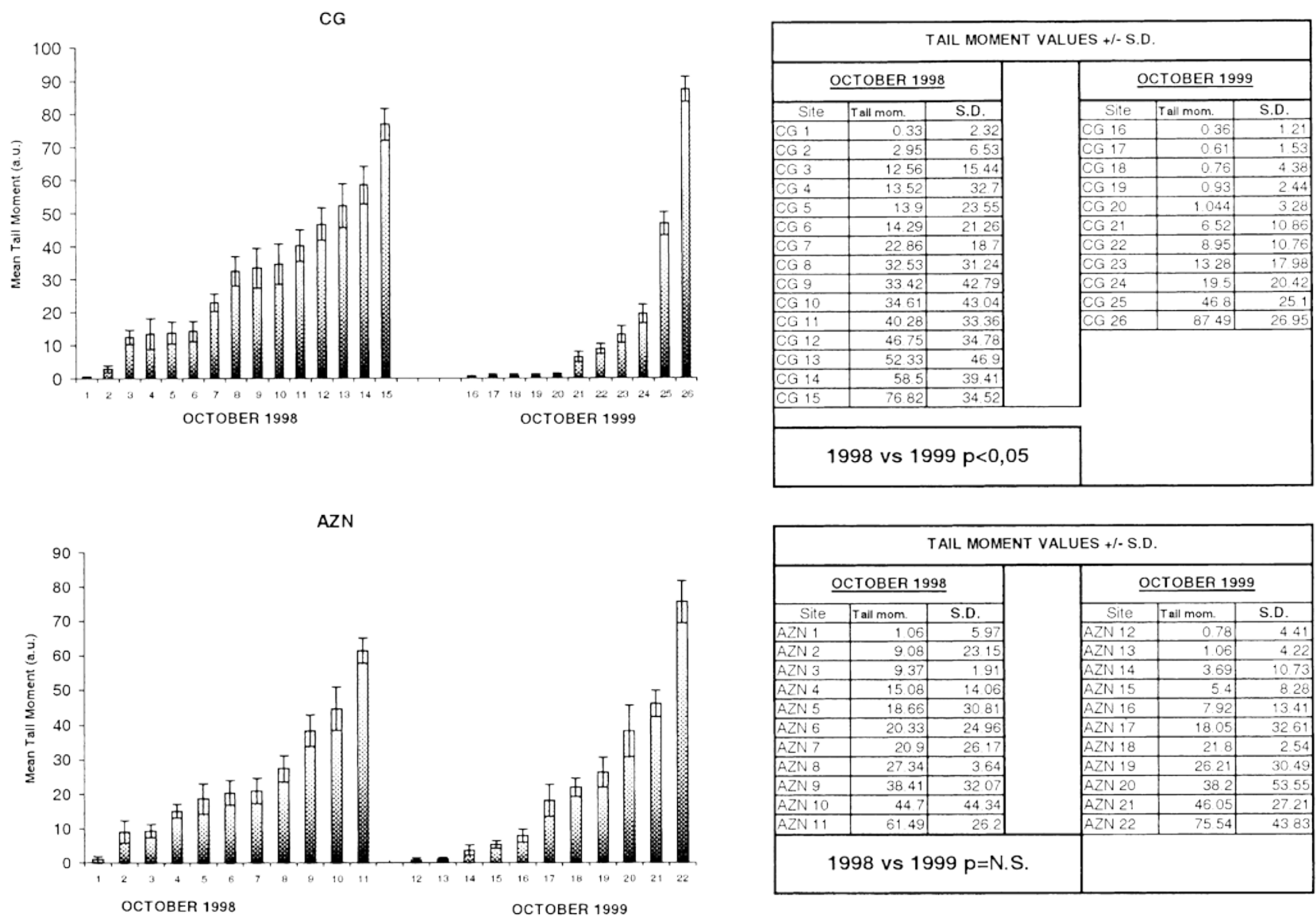

Fig. 2. DNA damage in the peripheral blood leukocytes of the animals collected in the CG and AZN sites. Each bar represents the mean tail moment7SE of 100 cells from a single mouse. In the tables alongside the graphs, the TM values 7 SDfound in each mouse are reported. The Mann-Whitney test was used for statistical comparison.

reported studies were carried out in organisms normally used in biomonitoring and toxicity tests, ranging from plants to worms, molluscs, fish, and amphibians; only one study, examining bottle-nosed dolphin (Tursiops truncatus) lymphocytes (Betti and Nigro, 1996), dealt with mammals. Recently da Silva et al. (2000) applied the Comet assay in genotoxicity biomonitoring using the wild rodent Ctenomys torquatus to detect the biological hazards of coal. On the whole, all reported data indicate that the Comet assay provides a sensitive system for the study of environmental genotoxicity.

In our study, the Comet assay was applied to detect the primary DNA damage possibly induced by the toxic spill of the Aznalcollar mine in Doñ ana National Park. The Comet assay was selected on the basis of its high sensitivity and rapidity. Furthermore, with this test DNA damage can be studied immediately after induction, before DNA repair occurs. One can also measure DNA strand breaks accumulated after continuous exposure to contaminants.

The first important observation is that the Comet parameters in all mice collected in the four different sites in the Park and along the Guadiamar River were higher than those from mice collected in 1999 in the BDT site. Furthermore, the TM values obtained in both samplings of the M. spretus were always higher than those found in the M. domesticus collected in Italy. In the latter case, we obtained a very low value of TM, 0.03570.0028 SD. This datum can be considered an internal control of a nonexposed condition, even though it was obtained in a sibiling species.

The high values of the Comet assay parameters in all the animals collected in 1998 in the AZN, CG, BDT, and RBDsites are indicative of the obvious contamination of the toxic spillage from the Aznalcollar pyrite mine. These results are in agreement with those of Tanzarella et al. (2001) showing high frequencies of micronuclei in the peripheral blood of the same group of mice collected in the same sites in 1998.

In particular, the contamination involved not only the two sites located outside the park (AZN and CG), but also the BDT site located inside the park and affected by the spread of the contaminated waters. To a lesser extent the TM values observed in the RBDsamples are 

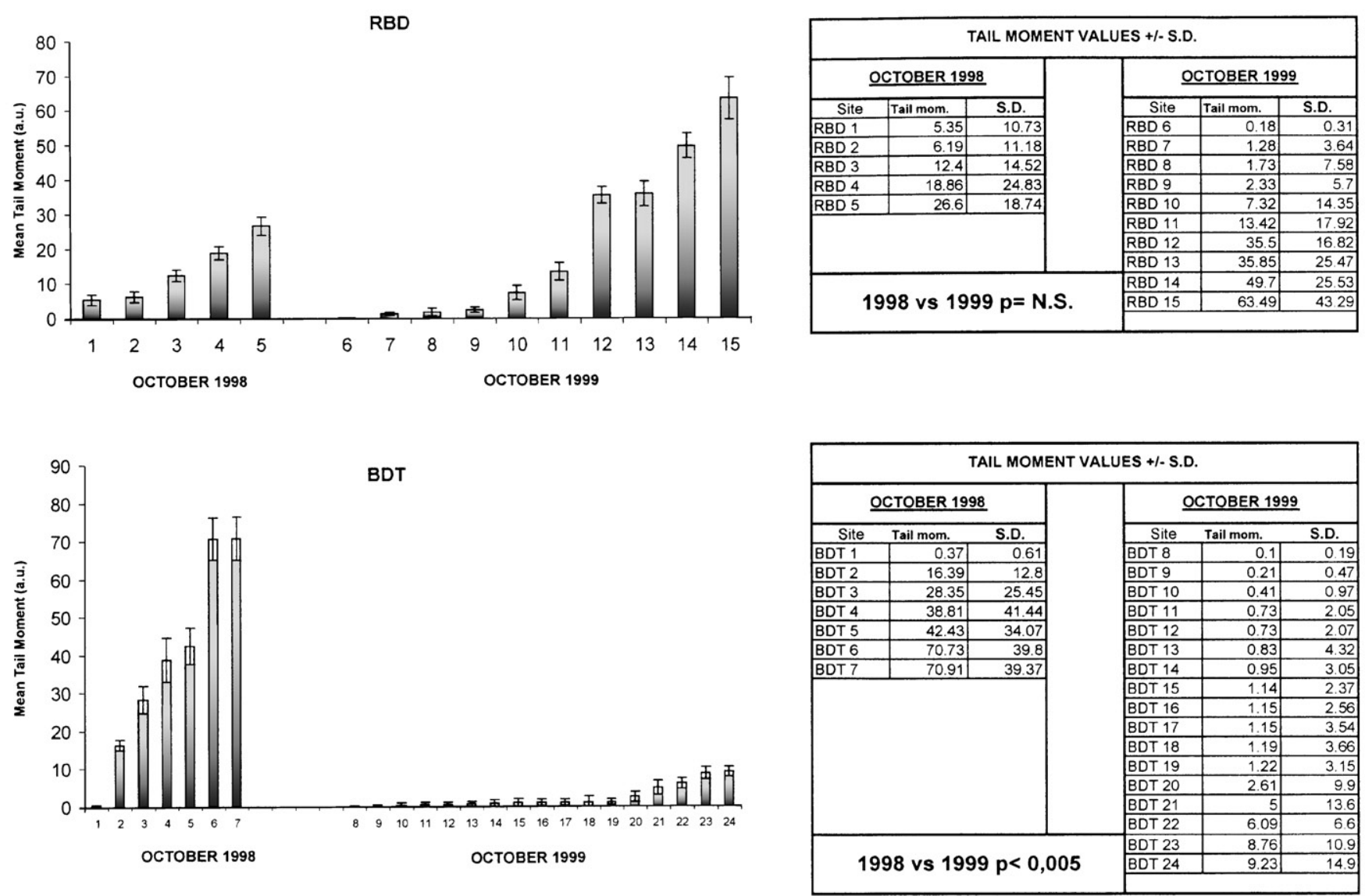

Fig. 3. DNA damage in the peripheral blood leukocytes of the animals collected in the RBD and BDT sites. Each bar represents the mean tail moment $7 \mathrm{SE}$ of 100 cells from a single mouse. In the tables alongside the graphs, the TM values 7 SDfound in each mouse are reported. The Mann-Whitney test was used for statistical comparison.

significantly higher than those from the BDT mice collected in 1999. This is probably due also to the presence of plaguicides and fertilizers used in the extensive rice fields on the left bank of the Guadiamar River upstream of Doñ ana National Park (Albaiges et al., 1987; Fernandez et al., 1992; Arambarri et al., 1996). Furthermore, a previous study carried out in two natural areas (Don ana Biological Reserve and Isla Cristina Marshland Natural Park) and in the Huelva industrial settlement showed a significant increase in the micronuclei frequencies in the $M$. spretus from the industrial area and Don ana Biological Reserve compared with those from Isla Cristina (Ieradi et al., 1998). Those results, coupled with ours, indicate that there was genetic damage in some mice populations of the Park area before the accident. Furthermore, chemical analyses conducted in this area show that the levels of heavy metals in soil and water had increased between 1982 and 1992 due to the mining activities (Hernandez et al., 1999; Martin et al., 2000).

We also compared the differences in mean DNA damage values among mice collected in 1999 in the same sites taking into account that the retaining wall built in
Entremuros could have reduced pollution in the downstream area (Fig. 1). Here we found a significant reduction of Comet assay parameters in the BDT mice compared to those in the AZN, CG, and RBDmice. This result is confirmed with the differences between the BDT animals in the 1998 and 1999 samplings. In this site, the significant decline of TM and \% DNA values between the 1998 and 1999 samplings shows a reduction of DNA damage due to a decrease in the concentration of contaminants, which are washed away by the tide flows present in the area and by the run-off of waters from the Guadiamar River (Grossi et al., in preparation).

Comparing all mice collected in the AZN and CG sites in 1998 with those collected in 1999, the differences observed in the mean TM values are not significant. In our opinion, this result indicates that a chronic contamination was still present 1 year after the disaster, in accordance with results presented by Pastor et al. (2001) in white storks collected in the same area in 1999. The values for the RBDmice were substantially unchanged when the 1998 and 1999 values were compared probably as a consequence of the absence in 
that area of tide flows. On the contrary, the frequent seasonal floods of marshlands may cause sedimentation of contaminants.

When we consider the single-mouse values, we observe a strong interindividual variability in all sites, except for those from the BDT sample collected in 1999. In our opinion, the analysis of exposed individuals is particularly interesting, as it takes into account the differences associated with repair ability or different metabolic status, which notably modify the response to exogenous agents (Tice et al., 1991; Maluf and Erdtmann, 2000). The comparison of each single mouse with the appropriate statistical analysis allowed a significant decrease in TM values to be recognized in CG mice collected in 1999 vs those collected in 1998 and a very significant difference between BDT mice collected in 1999 and those collected in 1998.

Finally, we propose that the significant reduction of DNA damage observed in juveniles collected in 1999 compared with those collected in 1998 may be a consequence of the nonhomogeneous structure of the population in the two sampling campaigns. In fact, almost half of the 1999 juveniles were sampled in the less contaminated BDT area (10 in BDT vs 9 in all the other sites), so that the lesser damage found in the 1999 juveniles can be ascribed to the prevalence of BDT juveniles rather than to a difference in sensitivity due to age.

The absence of an analysis by the Comet assay before the Aznalcollar spill prevents a comparison. However, we suggest that the situation described here is a consequence of the disaster, which has been partially recovered. Successive campaigns should be carried out to monitor the persistence of genotoxic alterations primarily inside Don ana Park. In addition, the Comet assay applied here for the first time in mice biomonitoring has proven to be a particularly suitable system for the study of the exposure of population groups to DNA-damaging agents.

\section{Acknowledgments}

This work was partially supported by the project "Seguimiento de Seres Vivos en el area afectada por el vertido de las minas de Aznalcollar"' (Convenio Junta de Andalucia-CSIC, Españ a). We acknowledge J. Ballestreros, C. Campoamor, A. Cappai, G. Chiuchiarelli, A. Jimenez, and L. Lombardi for their help during the mice capture and sample preparations.

\section{References}

Albaiges, J., Algaba, J., Arambarri, P., Cabrera, F., Baluja, C., Hernandez, L.M., Castroviejo, J., 1987. Budget of organic and inorganic pollutants in the Don ana National Park (Spain). Sci. Total Environ. 63, 13-28.

Alzaga, R., Mesas, A., Ortiz, L., Bayona, J.M., 1999. Characterisation of organic compounds in soil and water affected by pyrite tailing spillage. Sci. Total Environ. 242, 167-178.

Arambarri, P., Cabrera, F., Gonzales-Quesada, R., 1996. Quality evaluation of the surface waters entering the Donana National Park (SW Spain). Sci. Total Environ. 19, 185-196.

Benito, V., Devesi, V., Munoz, O., Suner, M.A., Montoro, R., Baos, R., Hiraldo, F., Ferrer, M., Fernandez, M., Gonzalez, M.J., 1999. Trace elements in blood collected from birds feeding in the area around Doana National Park affected by the toxic spill from the Aznacollar mine. Sci. Total Environ. 242, 309-323.

Betti, C., Nigro, M., 1996. The comet assay for the evaluation of the genetic hazard of pollutants in cetaceans: preliminary results on the genotoxic effects of methylmercury on the bottle-nosed dolphins. Mar. Pollut. Bull. 32, 545-548.

Blasco, J., Arias, A.M., Saenz, V., 1999. Heavy metals in organisms of the River Guadalquivir estuary: possible incidence of the Aznacollar disaster. Sci. Total Environ. 242, 249-259.

Cagnin, M., Moreno, S., Aloise, G., Garofalo, G., Villafuerte, L., Gaona, P., Cristaldi, M., 1998. A comparative study of Spanish and Italian terrestrial small mammal coenoses of different biotopes in Mediterranean peninsular tip regions. J. Biogeography 25, 1105-1113.

Cotelle, S., Ferard, J.F., 1999. Comet assay in genetic toxicology: a review. Environ. Mol. Mutagen. 34, 246-255.

Cristaldi, M., Ieradi, L.A., Licastro, E., Lombardi Boccia, G., Simeone, G., 1985. Environmental impact of nuclear power plants on wild rodents. Acta Zool. Fennica 173, 205-207.

Cristaldi, M., D’Arcangelo, E., Ieradi, L.A., Mascanzoni, D., Mattei, T., Van Axel Castelli, I., 1990. 137-Cs determination and mutagenicity tests in wild Mus musculus domesticus before and after the Chernobyl accident. Environ. Pollut. 64, 1-9.

Cristaldi, M., Ieradi, L.A., Mascanzoni, D., Mattei, T., 1991. Environmental impact of the Chernobyl accident: mutagenesis in bank voles from Sweden. Int. J. Radiat. Biol. 59, 31-40.

da Silva, J., de Freitas, T.R.O., Heuser, V., Marinha, J.R., Erdtmann, B., 2000. Genotoxicity biomonitoring in coal regions using wild rodent Ctenomys torquatus by comet assay and micronucleus test. Environ. Mol. Mutagen. 35, 270-278.

Degrassi, F., Tanzarella, C., Ieradi, L.A., Zima, J., Cappai, A., Lascialfari, A., Allegra, F., Cristaldi, M., 1999. CREST-staining of micronuclei from free-living rodents to detect environmental contamination in situ. Mutagenesis 14, 391-396.

Fernandez, M.A., Hernandez, L.M., Gonzales, M.J., Tabera, M.C., 1992. Organochlorinated compounds and selected metals in water and soils from Doñ ana National Park (Spain). Water Air Soil Pollut. 65, 293-305.

Grimalt, J.O., Ferrer, M., Machperson, E., 1999. The mine tailing accident in Aznalcollar. Sci. Total Environ. 242, 3-11.

Hernandez, L.M., Gomara, B., Fernandez, M., Jimenez, B., Gonzales, M.J., Baos, R., Hiraldo, F., Ferrer, M., Benito, V., Suñer, M.A., Devesi, V., Muñ oz Montoro, R., 1999. Accumulation of heavy metals and As in wetland birds in the area around Dothana National Park affected by the Aznalcollar toxic spill. Sci. Total Environ. 242, 293-308.

Ieradi, L.A., Cristaldi, M., Mascanzoni, D., Cardarelli, E., Grossi, R., Campanella, L., 1996. Genetic damage in urban mice exposed to traffic pollution. Environ. Pollut. 92, 323-328.

Ieradi, L.A., Moreno, S., Bolivar, J.P., Cappai, A., Di Benedetto, A., Cristaldi, M., 1998. Free-living rodents as bioindicators of genetic risk in natural protected areas. Environ. Pollut. 102, 265-268.

Maluf, S.W., Erdtmann, B., 2000. Follow-up study of the genetic damage in lymphocytes of pharmacists and nurses handling 
antineoplastic drugs evaluated by cytokinesis-block micronuclei analysis and single gel electrophoresis assay. Mutat. Res. 471, 21-27.

Martin, J.E., Garcia-Tenorio, R., Ontalba-Salamanca, M.A., Respaldiza, M.A., da Silva, M.F., 2000. TTPIXE analysis of Guadiamar river sediments collected before the environmental disaster of 1998. Nucl. Instrum. Methods Phys. Res. B 161-163, 825-829.

Meharg, A.A., Osborn, D., Pain, D.J., Sanchez, A., Naveso, M.A., 1999. Contamination of Dont ana food-chains after the Aznalcollar mine disaster. Environ. Pollut. 105, 387-390.

Olive, P.L., Banath, J.P., Durand, R.E., 1990. Heterogeneity in radiation-induced DNA damage and repair in tumor and normal cells using the "comet”' assay. Radiat. Res. 122, 86-94.

Pain, D.J., Sanchez, A., Meharg, A.A., 1998. The Don ana ecological disaster: contamination of a World Heritage estuarine marsh ecosystem with acidified pyrite mine waste. Sci. Total Environ. 222, 45-54.

Palomo, L.J., 1990. Caracteristicas de los desplazamientos del raton moruno, Mus spretus Lataste,1883 en cultivos de caña de azucar de la provincia de Malaga. Ecologia (Icona, Madrid) 4, 185-189.

Pastor, N., Lopez-Kazaro, M., Tella, J.L., Baos, R., Hiraldo, F., Cortës, F., 2001. Assessment of genotoxic damage by the Comet assay in white storks (Ciconia ciconia) after the Dont ana ecological disaster. Mutagenesis 16, 219-223.

Ruiz-Laguna, J., Garcia-Alfonso, C., Peinado, J., Moreno, S., Ieradi, L.A., Cristaldi, M., Lopez-Barea, J., 2001. Molecular biomarkers of pollution in Algerian mouse (Mus spretus) to assess the effects of Aznacollar disaster on Dont ana Park (Spain). Biomarkers 6, 146-160.
Singh, N.P., McCoy, M.T., Tice, R.R., Schneider, E.L., 1988. A simple technique for quantitation of low levels of DNA damage in individual cells. Exp. Cell Res. 175, 184-191.

Talmage, S.S., Walton, B.T., 1991. Small mammals as monitors of environmental contaminants. Rev. Environ. Contam. Toxicol. 119, 47-108.

Tanzarella, C., Degrassi, F., Cristaldi, M., Moreno, S., Lascialfari, A., Chiuchiarelli, G., Ieradi, L.A., 2001. Genotoxic damage in freeliving Algerian mouse (Mus spretus) after the Coto Dontana ecological disaster. Environ. Pollut. 115, 43-48.

Tice, R.R., Andrews, P.W., Hirai, O., Singh, N.P., 1991. The single cell gel (SCG) assay: an electrophoresis technique for the detection of DNA damage in individual cells. In: Witmer, C.R., Snyder, R.R., Jollow, D.I., Kalf, G.F., Kocsis, J.J., Sipes, I.G. (Eds.), Biological Reactive Intermediates. IV. Molecular and Cellular effects and Their Repair on Human Health. Plenum Press, New York, pp. 157-164.

Tice, R.R., Agurell, E., Anderson, D., Burlinson, B., Hartmann, A., Kobayashi, H., Miyamae, Y., Rojas, E., Ryu, J.-C., Sasaki, Y.F., 2000. Single cell gel/Comet assay: guidelines for in vitro and in vivo genetic toxicology testing. Environ. Mol. Mutagen. 35, 206-221.

Visvardis, E.E., Tassiou, A.M., Piperakis, S.M., 1997. Study of DNA damage induction and repair capacity of fresh and criopreserved lymphocytes exposed to $\mathrm{H}_{2} \mathrm{O}_{2}$ and g-radiation with the alkaline comet assay. Mutat. Res. 383, 71-80.

Visvardis, E.E., Haveles, K.S., Patarias, T.A., Margaritis, L.H., Sophianopoulou, V., Sideris, E.G., 2000. Diversity of peripheral blood mononuclear cells as revealed by a novel multiple microgel “Comet assay”. Environ. Mol. Mutagen. 36, 32-39. 